\title{
KARAKTERISASI DAN IDENTIFIKASI GENUS BAKTERI ENDOFIT DARI DAUN DAN BATANG JERUK SIAM (Citrus nobilis var. microcarpa) SEHAT DI DESA ANJUNGAN KALIMANTAN BARAT
}

\author{
Lusiana Fitriani Br. Silalahi ${ }^{1 *}$, Mukarlina ${ }^{1}$, Rahmawati $^{1}$ \\ ${ }^{1}$ Program Studi Biologi, Fakultas Matematika dan Ilmu Pengetahuan Alam, Universitas Tanjungpura, Pontianak \\ *Email korespondensi: Silalahilusiana14@gmail.com
}

\begin{abstract}
Endophytic bacteria that live in the tissues of plant organs act as biological control agents and growth accelerator such as for plants Siam Orange (Citrus nobilis var. microcarpa) which is included in main commodity horticultural crops in West Kalimantan. This study was aimed to know the genera of endophytic bacteria from healthy Siam Orange stems and leaves. The study was conducted through the steps of endophyte bacteria isolation, and identification. Systematic sampling method was used and data collected were descriptively analyzed. The study results obtained nine isolates from leaves of Bacillus, Micrococcus, Pseudomonas, Erwinia, Microbacterium, Cellulomonas and one unidentified isolate, one isolate from stems of Micrococcus
\end{abstract}

Keywords: Bacillus, Endophytic Bacteria, Micrococcus, Siam Orange (Citrus nobilis var. microcarpa)

\section{PENDAHULUAN}

Jeruk siam (Citrus nobilis var. microcarpa) merupakan salah satu tanaman holtikultura yang menjadi komoditas unggulan di Kalimantan Barat. Salah satu perkebunan di Kalimantan Barat terdapat Unit Pembenihan Induk Tanaman Pangan dan Holtikultura (UPITPH), di Desa Anjungan. Pohon jeruk siam yang ditanam merupakan hasil pembenihan yang dilakukan oleh UPITPH Anjungan. Bibit jeruk siam dari UPITPH ini merupakan bibit yang dikembangbiakan di Kecamatan Tebas, Kabupaten Sambas, Kalimantan Barat (Suliati et al., 2017).

Menurut Badan Pusat Statistik Provinsi Kalimantan Barat (2013), hasil produksi buah jeruk siam pada tahun 2013 mengalami penurunan menjadi 114.825 ton/tahun dari jumlah hasil produksi yang didapat pada tahun 2012 yang mencapai 146.769 ton/tahun. Yulianti (2012) menyatakan bahwa penurunan jumlah produksi tanaman jeruk siam salah satunya disebabkan oleh adanya organisme pengganggu tanaman (OPT). Pengendalian OPT dapat dilakukan secara biologis dengan bakteri endofit.

Bakteri endofit adalah organisme hidup yang berukuran mikroskopis yang hidup di dalam jaringan organ tumbuhan tanpa membahayakan inangnya. Bakteri endofit merupakan bakteri yang menguntungkan diantaranya dapat dimanfaatkan sebagai agen biokontrol, anti mikroba, anti inflamasi, antioksidan, dan anti diabetes (Rahmawati, 2009). Hallman \& Berg (2006) menyebutkan bahwa keunggulan bakteri endofit selain agen pengendali hayati juga mampu meningkatkan pertumbuhan tanaman yang dikenal dengan Plant Growth Promoting (PGP), karena mampu meningkatkan ketersediaan nutrisi, menghasilkan hormon pertumbuhan serta dapat menginduksi ketahanan tanaman yang dikenal dengan Induced Systemic Resistance (ISR).

Bakteri jenis Curtobacterium flaccumfaciens sebagai endofit yang diperoleh dari tanaman jeruk dapat membentuk ketahanan terhadap infeksi patogen Xylela fastidiosa (Lacava et al. 2002). Hasil penelitian Welington et al. (2002) dan Chongbi et al. (2015) menunjukkan bahwa hasil isolasi dari bagian organ berupa cabang daun tanaman jeruk sehat (Citrus jambhiri) diperoleh bakteri endofit diantaranya anggota spesies Alcaligenes sp., Bacillus pumilus, B. cereus, Burkholderia cepacia, Curtobacterium flaccumfaciens, Enterobacter cloacae, Methylobacterium spp., Nocardia sp., Pantoea agglomerans, Streptomyces sp., dan Xanthomonas campestris, serta telah ditemukan anggota bakteri endofit pada organ daun tanaman jeruk sehat, yaitu bakteri dari anggota genus Bacillus dan Agrobacterium. Berdasarkan latar belakang diatas maka penelitian tentang karakterisasi dan identifikasi genus bakteri endofit 
dari daun dan batang jeruk siam perlu dilakukan karena penelitian tersebut belum pernah dilakukan.

\section{BAHAN DAN METODE Waktu dan Tempat Penelitian}

Penelitian dilaksanakan selama 3 bulan dari bulan Agustus-November 2018. Pengambilan sampel batang dan daun tanaman jeruk siam yang sehat dilakukan di perkebunan UPITPH di Desa Anjungan, Kalimantan Barat. Tahap isolasi, identifikasi, serta uji proteolitik dilakukan di Laboratorium Mikrobiologi, Jurusan Biologi, Fakultas Matematika dan Ilmu Pengetahuan Alam, Universitas Tanjungpura, Pontianak.

Bahan-bahan yang digunakan adalah agar-agar bubuk 10 gram, akuades steril, alkohol 70\%, alkohol 96\%, FeSO4.7H2O 0,01 gram, Hidrogen Peroksida $\left(\mathrm{H}_{2} \mathrm{O}_{2}\right) 3 \%$, media MIO (Motility Indole Ornitin), MgSO4.7H2PO4 0,3 gram, $\mathrm{MnCl}_{2}$ 0,001 gram, media SCA (Simmon Citrate Agar), media TSA (Tryptic Soy Agar) (Farm Europe) 40 gram, media TSIA (Triple Sugar Iron Agar), media Urea Chrestensen, $\mathrm{NaOCl} 1 \%$, reagen Kovac, safranin, ZnSO4 0,001gram, sampel batang dan daun tanaman jeruk siam yang sehat dari UPITPH Anjungan.

\section{Prosedur Kerja}

\section{Sterilisasi Alat}

Alat-alat yang digunakan dalam penelitian yaitu cawan petri, erlenmeyer, gelas piala serta tabung reaksi disterilisasi dengan menggunakan autoklaf dengan tekanan $2 \mathrm{~atm}$ dan suhu $121^{\circ} \mathrm{C}$ selama 15 menit (Marlina, 2008).

\section{Pengambilan Sampel}

Pengambilan sampel batang dan daun tanaman jeruk siam menggunakan metode sistematis (systematic sampling) mengikuti metode Suliati et al. (2017) pengambilan sampel tanaman dengan cara menelusuri perkebunan jeruk siam yaitu pada garis diagonal silang tanaman, sehingga diperoleh lima sampel tanaman yang sehat, bagian tanaman yang diambil yaitu daun yang sudah dewasa, dan bagian batang yang dipilih adalah cabang kedua dari batang tanaman jeruk siam di kebun jeruk Kabupaten Anjungan, Kalimantan Barat.

\section{Isolasi Bakteri Endofit}

Metode isolasi bakteri endofit mengikuti metode dari Munif et al. (2012). Isolasi dilakukan pada bagian batang dan daun tanaman jeruk siam yang sehat dari kebun jeruk di desa Anjungan,
Kalimantan Barat. Bahan tanaman dicuci dengan air mengalir sampai bersih, kemudian masing-masing sampel dipotong menjadi beberapa bagian. Potongan daun disterilisasi dengan menggunakan alkohol $70 \%$ selama 30 detik, kemudian sampel direndam pada $\mathrm{NaOCl} 1 \%$ selama 60 detik. Potongan bagian batang disterilisasi dengan cara direndam dalam larutan alkohol $70 \%$ selama 60 detik, selanjutnya sampel direndam dalam $\mathrm{NaOCl} 1$ $\%$ selama 120 detik, kemudian dibilas dengan akuades steril sebanyak 3 kali lalu dikeringkan.

Sampel daun dan batang yang telah steril dihaluskan dengan mortar, setelah itu ditimbang sebanyak 1 gram. Sampel daun dan batang masing-masing sebanyak 1 gram dimasukkan ke dalam tabung reaksi berisi $9 \mathrm{ml}$ akuades, selanjutnya diambil $1 \mathrm{ml}$ dan dimasukkan ke tabung reaksi yang berisi $9 \mathrm{ml}$ akuades sehingga diperoleh pengenceran $10^{-1}$. Kemudian dilakukan dengan cara yang sama pada tabung reaksi lainnya sampai $10^{-4}$ (Fitriah et al. 2014). Selanjutnya diambil sebanyak $1 \mathrm{ml}$ dari setiap seri pengenceran dan dimasukkan ke dalam cawan petri yang berisi media TSA. Selanjutnya diinkubasikan di dalam inkubator dengan suhu $37^{\circ} \mathrm{C}$ selama $1 \times 24$ jam dan $2 \times 24$ jam, bakteri yang muncul selanjutnya dimurnikan pada media TSA baru (Waluyo, 2008).

\section{Pemurnian Isolat Bakteri Endofit}

Pemurnian dilakukan dengan cara mengambil koloni bakteri yang memiliki karakteristik yang berbeda pada tiap cawan petri. Koloni diambil dengan jarum ose dan digoreskan pada media TSA, kemudian diinkubasi selama 24-48 jam pada suhu $37^{\circ} \mathrm{C}$ (Waluyo, 2008).

\section{Karakterisasi Bakteri Endofit}

Karakterisasi bakteri endofit dilakukan melalui pengamatan karakter morfologis secara makroskopis, mikroskopis dan karakter fisiologis melalui uji biokimia (Waluyo, 2003).

\section{Pengamatan Makroskopis}

Pengamatan makroskopis koloni bakteri meliputi bentuk, elevasi, tepian dan warna koloni yang dihasilkan pada media TSA.

\section{Pengamatan Mikroskopis}

Pengamatan karakter mikroskopis dilakukan melalui pewarnaan gram, isolat bakteri dioleskan pada gelas objek dengan menggunakan jarum ose. Setelah merata dan kering, difiksasi di atas bunsen sebanyak tiga kali, kemudian ditetesi pewarna kristal violet dan dibiarkan selama 60 detik, lalu dibilas dengan air mengalir dan dikeringanginkan. 
Gelas objek ditetesi dengan larutan iod dan dibiarkan selama 60 detik, setelah itu dibilas dengan air mengalir dan dikeringanginkan.

Gelas objek lalu ditetesi dengan alkohol $96 \%$ dan dibiarkan selama 30 detik sampai warna ungu menghilang lalu dibilas dengan air mengalir dan dikeringanginkan. Setelah itu slide ditetesi dengan pewarna safranin dan dibiarkan selama 30 detik, lalu dibilas dengan air mengalir dan dikeringanginkan, kemudian diamati di bawah mikroskop. Bakteri gram positif akan berwarna ungu sedangkan bakteri gram negatif berwarna merah (Waluyo, 2008).

\section{Uji Biokimia}

Uji biokimia meliputi pengujian karakter fisiologis bakteri berdasarkan acuan Bergey's Manual of Determinative Bakteriology (Holt et al. 1994) yaitu uji katalase, uji oksidase, uji dekarboksilase, uji urea, uji motilitas, uji indol, uji Simmons Citrate Agar (SCA) dan uji Triple Sugar Iron Agar (TSIA).

\section{Identifikasi Bakteri Endofit}

Identifikasi bakteri endofit yang diisolasi dari daun dan batang jeruk siam dilakukan dengan melihat kesamaan ciri bakteri yang telah dikarakterisasi menggunakan buku kunci determinasi dari Cowan and Steel's Manual for the Identification of Medical Bacteria (Barrow \& Feltham, 1993) dan Bergey's
Manual of Determinative Bacteriology (Holt et al. 1994).

\section{Analisis dan Penyajian Data}

Data yang diperoleh dianalisis secara deskriptif berdasarkan karakter morfologis, hasil uji biokimia, deteksi proteolitik serta hasil identifikasi ditampilkan dalam bentuk Tabel dan Gambar (Foto).

\section{HASIL DAN PEMBAHASAN}

\section{Hasil}

Hasil isolasi bakteri dari daun dan batang tanaman jeruk siam ditemukan 10 isolat yaitu E1, E2, E3, E4, E5, E6, E7, E8, E9, dan F1. Karakter morfologis koloni bakteri yaitu bentuk, warna, elevasi, margin, ukuran isolat, bentuk sel dan gram bakteri masingmasing isolat dapat dilihat pada tabel 1 .

Berdasarkan hasil isolasi bakteri endofit dari sampel daun dan batang tanaman jeruk siam sehat, satu isolat diperoleh dari sampel batang tanaman jeruk siam yang sehat, sedangkan sampel daun tanaman jeruk siam diperoleh sebanyak sembilan isolat.

Hasil pengamatan morfologi sel bakteri dan uji biokimia yang dilakukan pada isolat bakteri yang meliputi gram, bentuk bakteri, serta hasil uji biokimia dapat dilihat pada tabel 2 .

Tabel 1. Karakter Morfologis Bakteri Hasil Isolasi dari Daun dan Batang Tanaman Jeruk Siam Sehat

\begin{tabular}{ccccccccc}
\hline & & & & & & & \\
Isolat & Bentuk & Warna & Elevasi & Margin & Ukuran & Sampel & Bentuk Sel & Gram \\
\hline E1 & Irregular & White & Flat & Lobate & Large & Daun & Basil & + \\
E2 & Irregular & White & Raised & Lobate & Moserate & Daun & Kokus & + \\
E3 & Filamentous & Cream & Raised & Serrate & Moserate & Daun & Basil & + \\
E4 & Circular & White & Raised & Entire & Large & Daun & Basil & + \\
E5 & Irregular & Cream & Convex & Entire & Large & Daun & Kokus & + \\
E6 & Filamentous & White & Flat & Lobate & Moserate & Daun & Basil & - \\
E7 & Irregular & White & Flat & Lobate & Small & Daun & Basil & + \\
E8 & Circular & White & Raised & Entire & Small & Daun & Basil & - \\
E9 & Irregular & White & Flat & Lobate & Small & Daun & Basil & + \\
F1 & Irregular & White & Flat & Entire & Large & Batang & Kokus & + \\
\hline
\end{tabular}


Tabel 2. Karakter Fisiologis dan Hasil Uji Biokimia Bakteri dari Daun dan Batang Tanaman Jeruk Siam

\begin{tabular}{ccccccccccc}
\hline Uji Biokimia & E1 & E2 & E3 & E4 & E5 & E6 & E7 & E8 & E9 & F1 \\
\hline Katalase & + & + & + & + & + & + & + & + & + & + \\
Motilitas & + & + & + & + & + & + & + & + & + & + \\
Indol & - & - & - & - & + & - & - & + & + & - \\
Ornithin & - & - & - & - & - & - & - & - & - & - \\
Citrat & - & + & - & - & - & + & - & - & - & + \\
Urea & - & - & - & + & + & + & + & - & - & - \\
Laktosa & - & + & - & - & - & + & - & + & + & - \\
Glukosa & + & + & + & + & + & + & + & + & + & + \\
Sukrosa & + & + & + & - & - & + & - & - & + & + \\
H 2 S & + & + & + & + & + & + & + & + & + & + \\
Oksidase & + & + & + & + & + & + & + & + & + & + \\
\hline
\end{tabular}

Keterangan uji biokimia : $+=$ Ada perubahan

- = Tidak ada perubahan

Berdasarkan hasil pengamatan karakter morfologis koloni, morfologis sel dan uji biokimia diperoleh enam genus bakteri endofit hasil isolasi dari daun dan batang jeruk siam, yaitu genus Bacillus, Micrococcus, Micrococcus Cellulomonas, Erwinia, Methylobacterium, dan Microbacterium dan satu isolat tidak diketahui genusnya (Unidentified).

Tabel 3. Genus Bakteri Endofit Hasil Isolasi dari Daun dan Batang Tanaman Jeruk Siam Sehat

\begin{tabular}{ccc}
\hline No. & Kode Isolat & Genus \\
\hline 1. & E1 & Bacillus \\
2. & E2 & Micrococcus \\
3. & E3 & Bacillus \\
4. & E4 & Cilulomonas \\
5. & E5 & Erwinitia \\
6. & E6 & Cellulomonas \\
7. & E7 & Methylobacterium \\
8. & E8 & Microbacterium \\
9. & E9 & Micrococcus \\
10. & F1 & \\
\hline
\end{tabular}

\section{Pembahasan}

Bakteri endofit dengan kode isolat E1 dan E3 memiliki persamaan karakter dengan anggota genus Bacillus yaitu sel berbentuk batang tersusun berpasangan dan bersifat gram positif. Hasil uji biokimia positif pada uji katalase, oksidase dan indol. Berdasarkan Holt et al. (1994), bahwa ciriciri mikroskopis bakteri anggota genus Bacillus yaitu sel berbentuk batang tersusun secara berpasangan dan bersifat gram positif, uji katalase positif, uji oksidase positif dan bersifat motil, bersifat aerob maupun anaerob fakultatif yaitu bakteri yang dapat menggunakan oksigen maupun tanpa oksigen dalam proses respirasi. Hasil penelitian Saputra et al. (2015) memperlihatkan hasil yang sama terhadap uji biokimia pada bakteri anggota genus Bacillus yaitu gram positif, uji katalase positif, melakukan metabolisme secara fermentasi atau respirasi anaerob, dan bersifat motil.

Bakteri endofit dengan kode isolat F1 dan E2 memiliki kesamaan karakter dengan anggota genus Micrococcus bersifat gram positif dan bentuk sel kokus tersusun tak beraturan dalam rantai, non motil dan menghasilkan enzim katalase. (Tabel 2). Berdasarkan Holt et al. (1994), bakteri anggota genus Micrococcus bersifat gram positif, bentuk sel kokus dalam bentuk berpasangan hingga bentuk kelompok tak beraturan dalam rantai, uji katalase dan oksidase positif, jarang yang motil. Hasil penelitian Towner (2017) menunjukkan bahwa anggota genus Micrococcus merupakan bakteri gram positif, umumnya berbentuk kokus, dan bersifat motil.

Bakteri endofit dengan kode isolat E4 dan E7 dengan anggota genus Cellulomonas memiliki beberapa karakter yang sama yaitu bentuk sel basil tersusun secara berpasangan, bersifat gram positif, katalase positif, bersifat motil, dan oksidase positif. Bakteri anggota genus ini mampu memfermentasikan glukosa, tidak mampu memfermentasikan laktosa dan sukrosa (Tabel 2). Berdasarkan Holt et al. (1994), bakteri anggota genus Cellulomonas merupakan bakteri gram positif, bentuk sel basil tersusun berpasangan, mampu menghasilkan enzim katalase, hasil positif pada uji oksidase dan uji urease, bersifat motil, menghasilkan asam dari glukosa dan gula-gula lain. Hasil penelitian Ristiati et al. (2016) menunjukkan bahwa genus Cellulomonas merupakan bakteri gram positif dan bersifat motil, bakteri gram positif dan bentuk sel basil, bersifat motil, dan hasil negatif pada uji indol. 
Berdasarkan hasil isolasi dan identifikasi, bakteri endofit dengan kode isolat E6 memiliki kesamaan karakter dengan anggota genus Erwinia berdasarkan uji biokimia memiliki karakter yaitu gram negatif, bentuk sel basil tersusun berpasangan, bersifat motil, katalase positif, indol negatif, uji sitrat positif, uji urea positif, menghasilkan $\mathrm{H} 2 \mathrm{~S}$ terdapat gas pada media uji TSIA (Tabel 2). Berdasarkan Holt et al. (1994), bakteri anggota genus Erwinia merupakan bakteri gram negatif, bentuk sel basil tersusun tunggal atau berpasangan, uji katalase positif, uji oksidase, urease dan sitrat positif dan indol negatif. Hasil yang sama ditunjukkan dalam penelitian Javandira et al. (2013) yaitu bakteri anggota genus Erwinia bersifat motil, gram negatif, serta uji katalase positif, indol negatif. Bakteri ini dapat menguraikan urea ditandai dengan perubahan warna media dari krem menjadi merah muda.

Bakteri endofit dengan kode isolat E8 memiliki kesamaan karakter dengan anggota genus Methylobacterium memiliki karakter mikroskopis yaitu gram negatif dan bentuk sel basil tersusun tunggal. Karakter bakteri ini berdasarkan uji biokimia yaitu katalase, oksidase, dan motil menunjukkan hasil positif, dan mampu memfermentasikan glukosa pada media TSIA. Berdasarkan Holt et al. (1994), bakteri anggota genus Methylobacterium merupakan bakteri gram negatif, berbentuk basil dengan tersusun secara tunggal atau kadang berkelompok, sebagian besar bersifat motil, dan indol positif. Uji oksidase dan katalase positif. Karakter yang sama ditunjukkan dalam hasil penelitian Winarwi (2006) yang menunjukkan bahwa bakteri anggota genus Methylobacterium memiliki sel berbentuk basil, bersifat gram negatif, motil, katalase positif, oksidase positif, mampu memfermentasikan glukosa.

Bakteri endofit dengan kode isolat E9 memiliki kesamaan karakter dengan anggota genus Microbacterium menunjukkan hasil uji biokimia yaitu gram positif dengan bentuk sel basil dengan tersusun tunggal, katalase dan oksidase positif. Isolat bakteri anggota genus Microbacterium mampu memfermentasikan glukosa, urease negatif dan indol positif (Tabel 2). Berdasarkan Holt et al. (1994), anggota genus Microbacterium memiliki bentuk sel basil tersusun tunggal atau berpasangan, ada yang bersifat motil dan beberapa bersifat non motil, bakteri anggota genus ini tidak mampu menguraikan urea, bakteri gram positif, pada uji indol dan uji katalase positif, membentuk asam dari glukosa pada uji TSIA. Hasil penelitian Wenzel et al. (2002) menunjukkan bahwa genus ini merupakan bakteri gram positif, bentuk sel basil yang tersusun tunggal, bersifat motil dan tidak mampu menguraikan urea.
Bakteri endofit dengan kode isolat E5 memiliki karakter morfologis yaitu gram negatif dan berbentuk kokus. Hasil uji biokimia yang diperoleh pada isolat E5 yaitu hasil positif pada uji motilitas, mampu menguraikan urea. Uji indol, katalase dan oksidase positif serta mampu memfermentasi glukosa pada uji TSIA (Tabel 2). Bakteri dengan kode isolat E5 belum diketahui genusnya karena ciri karakter makroskopis dan mikroskopis yang diperoleh tidak ada yang sesuai dengan karakter yang ada pada buku identifikasi bakteri (Bergey's Manual of Determinative Bacteriology).

Penelitian untuk memperoleh bakteri endofit pada tanaman lainnya sudah banyak dilakukan misalnya pada tanaman jagung. Fisher et al. (1992) melaporkan bakteri endofit yang diisolasi dari batang jagung ialah Pseudomonas corrugata, P. Fluorescens, P. Marginalis, Enterobacter agglomerans, Klebsiella terrigena. Demikian juga bakteri endofit Bacillus sp., Cellulomonas sp., Kurtia sp., Microbacterium sp., dan Pediococcus sp. (Orole \& Adejumo, 2011). Liu et al. (2012) melaporkan isolat bakteri endofit yang berasal dari benih jagung ialah genus Burkholderia, Methylobacterium, Limnobacter, Erwinia, Micrococcus dan Undibacterium.

\section{DAFTAR PUSTAKA}

Badan Pusat Statistik Kalimantan Barat, 2013, Dinas Perkebunan Provinsi Kalimantan Barat

Barrow, GI \& Feltham, RKA, 1993, 'Cowan and steel's manual for identification of medical bacteria', third edition, Cambridge University Press

Chongbi, Li, SN, Liang, FY, Gao, KN, Chen, J, Wang, M, Zhang, T, Sun \& XK, Mu, 2015, 'Isolation of Endophytic Bacteria and Amplification of $16 \mathrm{SrDNA}$ on Citrus in Zhaoqing Districts' Journal of Agricultural Science, vol. 7, no. 12, hal. 198-207

Fisher, PJ, Petrini, O, Scott, HM, 1992, The Distribution of some Fungal and Bacterial Endophytes in Maize (Zea mays L.), Journal New Phytol, vol. 1, no.22, hal. 299-305

Fitriah, B, Irwan, L \& Johanes, P, 2014, 'Eksplorisasi Bakteri Endofit Sebagai Agens Pengendalian Hayati Terhadap Penyakit Darah Pada Tanaman Pisang Secara InVitro', Jurnal Agrotekbis, vol. 2, no. 6, hal 579-586 
Hallman, J \& Berg, G, 2006, Spectrum and Population Dynamics of Bacterial Root Endophytes, di dalam: Schulz BJE, Boyle CJC, Sieber TN, editor, Microbial Root Endophytes, Springer, Jerman

Holt JG, Krig NR., Snearth P, Staley J, \& Williams S, 1994, 'Bergey's Manual of Determinative Bacteriology 9th Edition' : Lipincott Williams and Wilkins Company, Philadelphia (USA)

Javandira, C, Luqman, QA \& Abdul LA, 2013, 'Pengendalian Busuk Lunak Umbi Kentang (Erwinia carotovora) dengan memanfaatkan Agensi Hayati Bacillus subtilis dan Pseudomonas flourescens', Jurnal HPT, vol. 1, no. 1, hal. 90-97

Lacava, PT, Araujo, WL, Marcon, J, Maccheroni, W, \& Azevedo, JL, 2004, Interaction Between Endophytic Bacteria from Citrus Plants and the Phytopathogenic Bacteria Xylella fastidiosa, Causal Agent of CitrusVariegated Chlorosis, Letters in Applied Microbiology, vol. 39, no.10, hal. 55-59

Liu, Y, Zuo, S, Zuo, Y, Wang, J, \& Song,W, 2012, Investigation on Diversity and Population Succesion Dynamics of Endophytic Bacteria from Seeds of Maize (Zea mays) at Different Growth Stages, Ann Microbial, vol. 1, no. 63, hal. 71-79

Marlina, 2008, 'Identifikasi Bakteri Vibrio parahaemolitycus Dengan Metode Biologi dan Deteksi Gen ToxRnya Secara PCR', Jurnal Sains dan Teknologi Farmasi', vol. 13, no. 1 hal. 11-17

Munif A, Wiyono S, \& Suwarno, 2012, Pemanfaatan bakteri endofit untuk meningkatkan Pertumbuhan dan kesehatan tanaman padi gogo, Di dalam: Prastowo, Sulistiono, Suprayogi A, Saharjo BH, Prosiding Seminar Hasil-Hasil Penelitian Institut Pertanian Bogor; Bogor: LPPM IPB

Orole, OO \& Adejumo, TO, 2011, Bacterial and Fungal Endophytes Associated With Grains and Roots of Maize, Journal Ecol Natur Environ, vol. 3, no. 9, hal. 298-303

Rahmawati, D, 2009, 'Mikroba Endofit Solusi Bahan Baku Obat Yang Murah dan Ramah Lingkungan', Siaran Pers, Deputi Direktur kantor komunikasi UI
Ristiati, NP, Mulyadiharja, S, \& Adhiguna, RA, 2016, 'Isolasi dan Identifikasi Mikroorganisme Penghasil Enzim Selulase pada Rayap (Coptotermes curvignathus holmgen), Prosiding Seminar Nasional Riset Inovatif, ISBN 978-608-6428-04-2

Saputra, R, Arwiyanto, T \& Wibowo, A, 2015, 'Uji Aktivitas Antagonistik Beberapa Isolat Bacillus spp. Terhadap Penyakit Layu Bacteria (Ralstonia solanacearum) pada Beberapa Varietas Tomat dan Identifikasinya, Pros Sem Nas Mays Biodiv Indon, vol. 1, no. 5, hal. 1116-1122

Suliati, Rahmawati \& Mukarlina, 2017, 'Jenis-Jenis Jamur Endofit Tanaman Jeruk Siam (Citrus nobilis var. microcarpa) di Perkebunan Dungun Prapakan Sambas', Jurnal Protobiont, vol. 6, no. 3, hal. 173-181

Towner, KJ, 2017, 'Clinical Importance and Antibiotic Resistance of Micrococcus spp. Department of Microbiology and PHLS Laboratory, University Hospital, Queen's Medical Centre, Nottingham, NG7

Waluyo L, 2003, Mikrobiologi Lingkungan, pp. 266-270, Malang, UMM Press

Waluyo L, 2008, Teknik Metode Dasar Mikrobiologi : UMM Press, Malang (INA)

Welington, L, Araújo, Marcon, J, Maccheroni, W, Jan Dirk van E, Jim W,L \& João Lúcio A, 2002, 'Diversity of Bacterial populations and Their Interaction with Xylella fastidiosa in Citrus Plants', Applied and Environmental Microbiology, vol. 68, no. 10, hal. 4906-4914

Wenzel, MIS, M, Berchtold, P, Kampfer \& H, Konig, 2002, 'Aerobic and Facultatively Anaerobic Cellulolytic Bacteria from the gut oftermite Zootermopsis angusticollis, Journal of Applied Microbiology, vol. 9, no. 2, hal. 32-40

Winarwi, 2006, 'Uji viabilitas bakteri dan aktivitas enzim bakteri proteolitik pada media carrier bekatul', Skripsi, Universitas Sebelas Maret, Surakarta

Yulianti, T, 2012, 'Menggali Potensi Endofit untuk Meningkatkan Kesehatan Tanaman Tebu Mendukung Peningkatan Produksi Gula', Perspektif, vol. 11, no. 2, hal. 111-122 
